$\Phi=$

\title{
Effects of seed pre-treatments on the germination of Dioscoreophyllum cumminsii
}

\author{
Tolulope Olaseini Bamigboye ${ }^{1 *}$, Joshua Kayode ${ }^{2,3}$ \\ ${ }^{1}$ Department of Crop Production Technology, Federal College of Forestry, Ibadan, Oyo State, Nigeria \\ ${ }^{2}$ Department of Plant Science, Ekiti State University, Ado-Ekiti, Ekiti State, Nigeria \\ *Corresponding author E-mail: joshua.kayode@eksu.edu.ng
}

\begin{abstract}
The effect of various seed pre-treatments on the germination of Dioscoreophyllum cumminsii was examined in this study. The pretreatments included seeds with their testa removed, intact seeds soaked in GA3, seeds soaked in GA3 for one hour after which their gelatinous covers were removed, seeds soaked in GA3 for one hour after which their testa were removed and seeds tied in polythene for 2 days. Intact seeds sown directly without any treatment served as control. Results obtained revealed that while germination did not occurred in seeds whose testa were removed and seeds soaked in GA3 for1 hour after which their testa were removed, germination occurred in other treated seeds and the control. Also while germination occurred in the first 5 weeks in seeds soaked in GA3 and seeds soaked in GA3 for 1 hour after which their gelatinous covers were removed, germination first occurred in 9 days in seeds soaked in GA3 for 1 hour after which their gelatinous covers were removed and in 10 days in intact seeds soaked in GA3. Growth occurred in other treated seeds at 11-15weeks experimental time. At 25 weeks experimental time, intact seeds soaked in GA3 had the highest \% germination and the germination occurred within the shortest experimental time.
\end{abstract}

Keywords: Seed; Pre-Treatments; Emergence; Dioscoreophyllum cumminsii.

\section{Introduction}

The rapid rates of forest loss and degradation across the tropics have continued to increase the fragmentations of forest populations and increased the risk of species' extinction (Amusa 2011). In Nigeria as elsewhere, conservation of forest genetic resources is achieved through the protection of these resources in their natural habitat (in situ) or preservation of samples of the genetic diversity of endangered species away from their field habitats (ex situ) in facilities such as botanical gardens, seed gene banks, in-vitro gene banks, and field gene banks (Owunubi and Otegbeye 2004, Amusa 2011).

Nwoboshi (1982) and Aminu (2012) described seed as a key element in plant production that exercises a very great influence on the success and failures of both natural and artificial regenerations. Seed is of particular importance and a key element in both in situ and ex situ plant conservation activities. The propagation of most tropical plant species however, is constrained by recalcitrant seed germination as a result of dormancy (Nwoboshi 1982, Amusa 2011). Seeds of many species do not germinate well unless they are exposed to certain conditions; this state of not germinating unless the required conditions are met is called dormancy (Aminu 2012). In the natural environment the conditions may be exposure to fire or being eaten by animals. When seeds are eaten they are exposed to the hydrochloric acid in the stomach of the animal, and this breaks the dormancy without damaging the seed (Aminu 2012).

The degree of dormancy makes it difficult for seed to germinate evenly and adequately (Amusa 2011). Hard, impervious seed coats are barriers to moisture and gas movement, as well as, a restriction to seedling development in many legumes (Craker and Barton
1957, Latting 1961 and Villiers 1972). Nwoboshi (1982) regarded seed dormancy as an obstacle to success of a nursery man whose aim is to obtain the largest possible number of seeds sown, germinating in the shortest possible time. Every normal seed contains an embryo (sometimes more than one) which will develop into seedling and have a supply of reserve substances which will sustain the seedling in the embryo stages of growth before it becomes self supporting (Black and Halmer 2006).

Dioscoreophyllum cumminsii (Stapf) Diels is a member of the Menispermaceae (Moonseed) family. It is a climbing vine with heart-shaped leaves (Inglett 1981, Kayode and Bamigboye 2016). The species have a complex life cycle; the males propagate asexually by subterranean tubers, which might have impacted on the species genetic variability, while the females reproduce sexually by seeds (Obioh and Isichei 2007). D. cumminsii sprouts from underground tubers or seeds which germinate at the onset of the rainy season between April and May, flower buds and inflorescence appear, followed by fruit production on female plants around late July and early August. The berries which are produced at basal positions along the hairy vine ripen from September through October, while the aerial vegetation dies back at the onset of dry season between November and December (Oselebe et. al. 2004). In Nigeria, it grows in the relatively undisturbed rainforest areas of Southern Nigeria. The plant is highly understudied and underutilized (Isikhuemen et. al. 2015). It has been found to have some unique properties. It is a potential source of noncarbohydrate sweetener because of the constituent active ingredient known as monellin, which is 3000 times sweeter than sugar and is useful in low calorie diets for diabetics and dieters, combating tooth decay and as a protein sweetener in the food industry (Holloway 1977). The total carotenoid content of D. cumminsii indicates that it has various health benefits and physiological ef- 
fects of vitamin A, particularly its benefits on vision, disease resistance, cell integrity, bone re-modeling and reproduction (IITA 2008). The vitamin C content of D. cumminsii according to Abiodun and Akinoso (2014) is $12.80 \mathrm{mg} / 100 \mathrm{~g}$, which is more than the vitamin $\mathrm{C}$ of local orange, watermelon and banana (Tee et. al. 1988). It was reported that the fruit is useful for human health and could be substituted for citrus fruits (Abiodun and Akinoso 2014). The major challenge facing this unique plant is its propagation through seed (Isikhuemen et. al. 2015). Limited studies have been carried out on seed propagation of D. cumminsii (Okoro 1976, Okoro 1980, Holloway 1977, Adansi and Holloway 1977). Cultivation and mass propagation of $D$. cumminsii have been difficult due to problems associated with seed dormancy (Holloway 1977, Okoro 1980). In natural habitats, seeds take about $4-7$ months to germinate (Okoro 1976, Adansi and Holloway 1977). The aim of this study is to examine the effects of various pre-treatments on the germination of the seeds of this important plant.

\section{Materials and methods}

Fresh fruits of $D$. cumminsii were collected from ten (10) mother plants and thoroughly mixed before selection. Seed extraction was carried out 24 hours after collection by depulping. Viability test was carried out on the extracted seeds after which the viable seeds were divided into seven groups of 30seeds each. The seeds were subjected to different pretreatments as follow:

$\mathrm{T}_{1}=$ Intact Seeds (Control)

$\mathrm{T}_{2}=$ Seeds with their gelatinous membrane removed

$\mathrm{T}_{3}=$ Seeds with their testa removed

$\mathrm{T}_{4}=$ Intact seeds soaked in $\mathrm{GA}_{3}$

$\mathrm{T}_{5}=$ Seeds soaked in $\mathrm{GA}_{3}$ for 1 hour after which their gelatinous covers were removed

$\mathrm{T}_{6}=$ Seeds soaked in $\mathrm{GA}_{3}$ for 1 hour after which their testa were removed

$\mathrm{T}_{7}=$ Seeds tied in polythene for 2 days

In each of these treatments, five treated seeds were sown in Petridish double-lined with Whatman No.1 filter papers and moistened with distil water. Each treatment was replicated six times. The seeds germination were observed and recorded over a period of 25 weeks.

\section{Results}

Table 1 show the results obtained in this study. The results revealed that seedlings germinated from seeds in treatments $\mathrm{T}_{4}$ and $\mathrm{T}_{5}$ within the first 5 weeks experimental time. Germination occurred in the 11-15 weeks experimental time in $T_{1}, T_{2}$ and $T_{7}$ While the first seedlings in $\mathrm{T}_{5}$ were observed at 9 days experimental time and with a total of $50 \%$ germination within 10 weeks (Table 1), the first seedlings in $\mathrm{T}_{4}$ were observed at 10 days experimental time with $70 \%$ germination within 10 weeks experimental time.

No emergence was observed in the naked seeds, Treatments $T_{3}$ and $\mathrm{T}_{6}$. Seeds in these treatments were observed to grow fungi within 7 to 12 days experimental time. Germinations were observed in Treatments $T_{1}$ and $T_{2}$ at 12 weeks (84 days) and 11 weeks ( 80 days) experimental time respectively.

Table 1: Germination in Pre-Treated Seeds of D. Cumminssi

\begin{tabular}{lllllll}
\hline \multirow{2}{*}{ Treatment } & \multicolumn{6}{c}{ \% Seed Germination / Experimental Time (Weeks) } \\
& $0-5$ & $6-10$ & $11-15$ & $16-20$ & $21-25$ & Total \\
\hline $\mathrm{T}_{1}$ & - & - & 20 & 20 & 10 & 50 \\
$\mathrm{~T}_{2}$ & - & - & 10 & 30 & 20 & 60 \\
$\mathrm{~T}_{3}$ & - & - & - & - & - & - \\
$\mathrm{T}_{4}$ & 60 & 10 & - & - & - & 70 \\
$\mathrm{~T}_{5}$ & 40 & 10 & - & - & - & 50 \\
$\mathrm{~T}_{6}$ & - & - & - & - & - & - \\
$\mathrm{T}_{7}$ & - & - & 10 & 10 & 10 & 30 \\
\hline
\end{tabular}

The results further revealed that Treatment $\mathrm{T}_{4}$ had the highest $\%$ germination $(70 \%)$ at the $21-25$ experimental time while the least
(30\%) was obtained in Treatment $\mathrm{T}_{7}$. Treatments $\mathrm{T}_{2}$ had $60 \%$ germination while $T_{1}$ and $T_{5}$ had $50 \%$ seed germinations thus suggesting that the best pre-germination treatment for seeds of $D$. cumminssi was by soaking in $\mathrm{GA}_{3}$ as this helped to break the dormancy and reduce seed germination from 12 weeks (80days) in $T_{1}$, $\mathrm{T}_{2}$ and $\mathrm{T}_{7}$ to 10 days in $\mathrm{T}_{4}$. Also, the intact seeds soaked in $\mathrm{GA}_{3}$ $\left(\mathrm{T}_{4}\right)$ had better seed germination than the scarified seeds soaked in $\mathrm{GA}_{3}\left(\mathrm{~T}_{5}\right)$ at the end of the experiment.

\section{Discussion}

The results obtained from this study suggest the need for pretreatments to improve seed germination in this species. The results obtained from Treatments $\mathrm{T}_{2}$ and $\mathrm{T}_{5}$ tends to lend credence to the previous assertion of Owunubi et. al. (2005) that chipping the fruits of Pterrocarpus anogeisus at one edge hasten its germination. Gibberellins are now known to influence all developmental and physiological processes in plants (Patel and Mankad 2014). Previous studies have enumerated the use of gibberellins as most potent germination promoter that break dormancy in a number of plants. These include the studies of Sharma (1982) on beans and peas, Utheib et. al. (1982) on potato, Bewley (1980), Kojimaa and Oota (1980), Sharma and Barooah (1986) on lettuce, Lopper and Waller (1982) on onion, Pawar et al. (1977) on radish, Adlakha and Verma (1965) on tomato, and Pulevitch et. al. (1977) on rare vegetables.

\section{Conclusion}

The results obtained from this study revealed that soaking of intact seeds in $\mathrm{GA}_{3}$ appeared to be seamless, highly effective and applicable to both small and large scale operations.

\section{Acknowledgement}

We acknowledged the receipt of TETFUND grant through Ekiti State University, Ado-Ekiti, Nigeria, for this study

\section{References}

[1] Abiodun OA, Akinoso R. (2014). Physico-chemical properties of serendipity berry (Dioscoreophyllum cumminsii) fruit. Journal of Applied Science and Environmental Management 18(2), 218-221.

[2] Adansi MA, Holloway HLO (1977). Seed germination and establishment of the serendipity berry, Dioscoreophyllum cumminsii. Diels. Acta Horticulturae 53, 407-411. http://dx.doi.org/10.17660/ActaHortic.1977.53.57.

[3] Adlakha PA, Verma SK (1965).After effects of phytochrome treatment of tomato seeds. Science and culture 31, 246-248.

[4] Aminu MB (2012). Different pre-germination treatments and Delonix regia seeds. JORIND 10(2), 24.

[5] Amusa TO (2011). Effects of three pre-treatment techniques on dormancy and germination of seeds of Afzelia africana (Sm. Ex pers). Journal of Horticulture and Forestry 3(4), 96-103.

[6] Bewley JD (1980). Secondary dormancy (Skoto dormancy) on seeds of lettuce (Lactuca sativa cv. Grand Rapids) and its release by light, Gibberellic Acid and Benzy ladenine. Physiol. Plant 49(3), 277-280. http://dx.doi.org/10.1111/j.1399-3054.1980.tb02663.x.

[7] Black MH, Halmer P (2006). The encyclopedia of Seeds: Science, Technology and Uses. CABI, Wallingford, UK, 224pp.

[8] Cracker W, Barton LV (1957). Physiology of seeds. Chronica Botanica Co. Waltham.

[9] Holloway HLO (1977). Seed propagation of Dioscoreophyllum cumminsii, source of an intense sweetener. Economic Botany31, 17-50. http://dx.doi.org/10.1007/BF02860651.

[10] IITA (2008). Yam research for development, International Institute for TropicalAgriculture, Ibadan, Nigeria, 10pp.

[11] Inglett GE (1981). Unusual sweeteners of plant origin. Food Technology 35(3), 31-41.

[12] Isikhuemen OY, Nwaoguala CNC, Odewale JO, Eke CR, Isikhuemen EM, Shittu HO (2015). In Vitro Morphogenetic Responses of 
Dioscoreophyllum cumminsii (Stapf) Diels Seed Explant. International Journal of Basic Science and Technology 1(1), $1-6$.

[13] Kayode J, Bamigboye TO (2016). Assessment of on-farm cultivation and conservation of indigenous fruit species in Ekiti State, Nigeria. Journal of Agriculture and Ecology Research International 7(3), 1-6. http://dx.doi.org/10.9734/JAERI/2016/24811.

[14] Kojimaa H, Oota U (1980). Promotion be Gibberellin of lettuce seed germination as a function of presoaking period. Plant cell Physiol. 21(4), 561-569.

[15] Latting J (1961). The biology of Desmanthus illionoensis. Ecology42, 487-493. http://dx.doi.org/10.2307/1932234.

[16] Lopper GM, Waller GD (19820. GA3 increased bolting and seed production in late planted onions. Hort. Science 17(6), 922-923.

[17] Nwoboshi LC (1982). Tropical Silviculture: Principles and Techniques. Ibadan University Press, Ibadan, Nigeria, 333p.

[18] Obioh GIB, Isichei AO (2007). A population viability analysis of serendipity berry (Dioscoreophyllum cumminsii) in a semideciduous forest in Nigeria. Ecological Modeling 201, 558-562. http://dx.doi.org/10.1016/j.ecolmodel.2006.10.007.

[19] Okoro OO (1976). Propagation of Dioscoreophyllum cumminsii. Nigerian Journal of Forestry 6, 70.

[20] Okoro OO. (1980). Propagation of Dioscoreophyllum cumminsii. Nigerian Journal of Forestry 10, 48-57.

[21] Oselebe HO, Ene-Obong EE, Nwankiti OC (2004). The biology of D. cumminsii (Stapf) Diels. Nigerian Journal of Botany 17, 17-28.

[22] Owunubi JJ, Otegbeye GO (2004). Disappearing forests: A Review of the challenges for conservation of Genetic Resources and Environmental Management. J. Res. Manage. 1 \& 2, $1-11$.

[23] Owunubi JJ, Otegbeye GO, Nwokedi C (2005). Development of pre-germination techniques for Azadirachta indica : Preliminary investigation. Pp 29 - 38. In L. Popoola, P. Mfon and P. I. Oni (Eds.) Sustainable Forest Management in Nigeria: Lessons Prospects. Proceedings of the 30th Annual Conference of the Forestry Association of Nigeria, Kaduna, Kaduna State. 7 - 11th November, 2005.

[24] Pawar PR, Joshi AT, Mahakal KG (1977). Effect of seed treatment with gibberellic acid on germination, growth and yield of radish (Raphanus sativus L). J. Maharashtra Agri. Uni. 2(1), 63-64.

[25] Pulevitch E, Mangagem I, Pressman E (1977). Effect of presowing gibberellins treatment of celery seed on the growth of seedlings in an unshaded nursery. Hassadeh 57(8), 1429-1433.

[26] Sharma, C. (1982). Effect of hormonal treatment during seed development on the vigour of subsequently formed seeds of pea (Pisum sativum L). Indian J. Pl. Physiol. 25(4), 371-381.

[27] Sharma M, Barooah A. (1986). Interact on between gibberellic acid and potassium nitrate on the germination of positive photoblastic lettuce seeds. Indian Agriculturist 30(2), pp. 165- 169

[28] Tee ES, Young SI, Ho SK, Mizura SS (1988). Determination of Vitamin $\mathrm{C}$ in Fresh Fruits and Vegetables Using the Dye-titration and Microfluorometric Methods. Pertanika 11(1), 39-44.

[29] Tengnäs B (1994). Agroforestry extension manual for Kenya. International Centre for Research in Agroforestry. Nairobi, Kenya.

[30] Utheib NA, Abbas MA, Sammara AS, Alumni MDP (1982). The effect of some growth regulators and thio urea on dormancy and subsequent growth of the potato in Basrah, J. Indian Potato Assoc. 8(3), 134-141.

[31] Villiers TA (1972). Seed dormancy. Pp. 219-281.1n:T.T. Kozlowski (Ed.). Seed Biology. Academic Press Inc., New York. http://dx.doi.org/10.1016/b978-0-12-424303-3.50009-9. 